taxing authority that a taxable interest in land had been created; otherwise such property rights would be subject to extinguishment. Under these circumstances, the taxing authority, as well as the courts, would be able to determine the existence of taxable interests by glancing at the tax rolls, and there would be little additional administrative expense.

Extinguishment should not, of course, be used as a substitute for eminent domain. Where the taxing authority, in order to resell forfeited land and recover delinquencies thereon, desires to extinguish known outstanding property interests, proceedings in the nature of condemnation would seem appropriate. Compensation would be measured by the loss to the owner of the dominant tenement ${ }^{67}$ and in many cases would be negligible. If the value of the interest is found to be substantial, however, the taxing authority might take occasion to revaluate the dominant tenement for purposes of more accurate assessment.

\title{
LIABILITY FOR PERSONAL INJURIES FROM DEFECTIVE HOUSING
}

The increasing growth of housing developments coupled with the possibility of choosing the size, style and color of a house from a "model" home is encouraging the average man to purchase his house in much the same manner as he purchases his automobile. The appearance of giant subdividing and construction corporations and the extensive use of such devices as the package mortgage ${ }^{1}$ and low-cost installment land contracts have made such purchases possible. Section 15 of the Uniform Sales Act and such cases as Carter v. Yardley \& Co. ${ }^{2}$ in protecting buyers from defects in purchased goods indicate how the law of chattels has kept pace with the growing commercialization of our society. But with regard to real property the classical doctrine insists:

Whatever may be the reason, no case has been found in the books where the vendor has been held liable in damages to the vendee, or to third persons, for personal injuries arising from defects in the premises: ${ }^{3}$

The extent and possibility of deviation from such a doctrine is of vital concern in an economy with an increasing volume of dwelling construction.

Although the trend is toward purchase of the house as a completed product, many prospective homeowners buy land and personally contract for construc-

\footnotetext{
or For a full discussion of condemnation of easements and covenants, see Aigler, Measure of Compensation for Extinguishment of Easements by Condemnation, [1945] Wis. L. Rev. 1.

${ }^{1}$ See Package Mortgage and Optional Future Advances, 65 Harv. L. Rev. 478 (1952), for the suggestion that the package mortgage aids those purchasers who would otherwise be unable to afford such utilities.

2319 Mass. 92, 64 N.E. 2d 693 (1946) (recovery by consumer from manufacturer for burns inflicted by perfume).

${ }^{3}$ Smith v. Tucker, 151 Tenn. 347, 362, 270 S.W. 66, 70 (1925). See also Combow v. Kansas City Ground Investment Co., 358 Mo. 934, 218 S.W. 2d 539 (1949).
} 
tion of the house. If, in this situation, a personal injury results from negligent construction, the homeowner is able to recover. ${ }^{4}$ By contracting to build the house, the builder impliedly warrants that he will build prudently-without negligence. In effect, he warrants the quality of his effort although not the quality of his product. ${ }^{5}$ Because of the contractual nature of this responsibility, it extends only to those privy to the contract. That occasionally members of the homeowner's family have been included among privies ${ }^{6}$ may mean no more than that they were within the foreseeable risk of danger, proof of which is necessary to a third party's cause of action against the builder.

If, as frequently happens, the homeowner purchases a completed house either from a large commercial developer or an individual homeowner, he has not participated in the contract of building, and consequently stands in relation to the builder merely as a third party. Traditionally, the rights of third parties to recover for personal injuries have been limited.

[I] $t$ is a general rule that a contractor, manufacturer, vendor, or furnisher of an article is not liable to third parties who have no contractual relations with him for negligence in the construction, manufacture, or sale of the article. ${ }^{7}$

This rule is still applied in cases in which subsequent owners or other third parties are injured by defects in the "real property per se," e.g., such as the collapse of the general structure itself. ${ }^{8}$ However, when the injury is not caused by defects in the "real property per se" but is, instead, attributable to a defect in some part of the real property which can be recognized as functionally separate, exceptions to the general rule are applied and recovery is allowed. So while defects in a porch railing, ${ }^{9}$ a gas heater, ${ }^{10}$ an overhead door ${ }^{11}$ have afforded recovery from the builder, recovery has been denied for injuries incurred from the collapse of a theater building. In denying recovery, the court acknowledged

The principle is well known in tort law that the duty on which negligence must be founded can arise from contract. Cowles v. Independent Elevator Co., 22 Cal. App. 2d 109, 70 P. 2d 711 (1937); Aetna Ins. Co. v. Illinois Central R. Co., 365 Ill. 303, 6 N.E. 2 d 189 (1937). The duty is the same as the law places upon all persons - to act as reasonable men under the circumstances. For particular reference to the builder, see"Curtin v. Somerset, $140 \mathrm{~Pa} .70,21 \mathrm{Atl}$. 244 (1891); 9 C.J., Building and Construction Contracts $\$ \$ 83-84$ (1916).

${ }^{5}$ Warranties which arise in the sale of chattels are warranties of the quality of the product since they impose not merely liability for negligence but absolute liability upon the warrantor. Lollar v. Jones, 229 Ala. 329, 157 So. 209 (1934); Pelletier v. DuPont, 124 Me. 268, 128 Atl. 186 (1925); Should the Doctrine of Implied Warranties Be Limited to Sales Transactions?, 2 Vanderbilt L. Rev. 675 (1949); and Prosser, Torts \& 82 (1941).

${ }^{6}$ McGuire v. Dalton Co., 191 So. 168 (La. App., 1939) (owner's wife); Grodstein v. McGivern, $303 \mathrm{~Pa} .555,154$ Atl. 794 (1931) (owner's daughter).

7 Ford v. Sturgis, 14 F. 2d 253, 255 (App. D.C., 1926).

Ibid.; Schott v. Ingargolia, 180 So. 462 (La. App., 1938).

'Murphy v. Barlow Realty Co., 206 Minn. 527, 289 N.W. 563 (1939); Hale v. Depaoli, 33 Cal. 2d 228, 201 P. 2d 1 (1948).

${ }^{10}$ Davey v. Turner, 55 Ga. App. 786, 191 S.E. 382 (1937).

11 Johnson v. Long, 56 Cal. App. 2d 834, 134 P. 2d 409 (1943). 
exceptions to the general rule, but refused to hold them applicable to "real property per se."'12

Among the exceptions which hold the builder and the manufacturer liable, perhaps the most significant is the negligent manufacture of an inherently dangerous article. ${ }^{13}$ In extending the inherently dangerous concept from articles by their nature dangerous to life and health to articles which are known to be dangerous if negligently constructed, MacPherson v. Buick ${ }^{14}$ relied heavily on Devlin v. Smith ${ }^{15}$ which allowed recovery from a scaffold builder for injury incurred by the collapse of the scaffold. Under MacPherson v. Buick, the negligent construction exception thus legitimately applies to building contractors. ${ }^{16}$ Broad application of this doctrine has induced the courts to consider the exception as the "general rule"17 and in some cases to allow recovery without a specific showing of negligence through the use of res ipsa loquitur..$^{18}$

Exceptions to the rule of nonliability may be found also when injury results from a nuisance per $\mathrm{s}^{19}$ and when an injurious defect is wilfully produced ${ }^{20}$ or fraudulently concealed. ${ }^{21}$ Likewise, recovery for injuries from the use of equipment unfit for its intended purpose has been allowed on the ground that the sale by the manufacturer of such defective equipment is an implied invitation to the ultimate user. ${ }^{22}$ In holding the manufacturer liable to third parties, the courts have even gone so far as to find a unilateral contract between the manufacturer

12 Ford v. Sturgis, 14 F. 2d 253, 255 (App. D.C., 1926).

${ }^{13}$ See Ievi, An Introduction to Legal Reasoning (1949) for an analysis of the evolution of this concept.

14 MacPherson v. Buick Motor Co., 217 N.Y. 382, 111 N.E. 1050 (1916).

${ }^{15}$ Devlin v. Smith, 89 N.Y. 470 (1882).

${ }^{18}$ See Moran v. Pittsburgh-Des Moines Steel Co., 166 F. 2d 908 (C.A. 3d, 1948); Murphy v. Barlow Realty Co., 206 Minn. 527, 289 N.W. 563 (1930); Dahms v. General Elevator Co., 214 Cal. 733, 7 P. 2 d 1013 (1932); Rest., Torts § 385 (1934).

${ }^{17}$ Carter v. Yardley \& Co., 319 Mass. 92, 64 N.E. 693 (1946).

${ }^{18}$ Escola v. Coca Cola Bottling Co. of Fresno, 24 Cal. 2d 453, 150 P. 2d 436 (1943); Tingey v. Houghton \& Co., 172 P. 2d 715 (Cal. App., 1946). On the use of res ipsa loquitur under the MacPherson v. Buick exception, see Manufacturers' Liability-MacPherson v. Buick Comes of Age, 4 Univ. Chi. L. Rev. 461, 466-67 (1937).

19 Schumacher v. Neuman Dredging and Improvement Co., 206 Wis. 220, 239 N.W. 459 (1931) (recovery allowed); Winterbottom v. Wright, 10 M. \& W. 107 (1842); Longmeid v. Holliday, 155 Eng. Rep. 752 (1851) (nuisance theory recognized); and Albany v. Cunliff, 2 N.Y. 165 (1849) (theory recognized but qualified by requirement that creator of nuisance continue to derive benefit).

20 Murphy v. Barlow Realty Co., 206 Minn. 527, 289 N.W. 563 (1939).

${ }^{21}$ Langridge v. Levy, 2 M. \& W. 519 (1937); Keulling v. Roderick Mfg. Co., 183 N.Y. 78, 75 N.E. 1098 (1905); and Travis v. Rochester Bridge Co., 186 Ind. 79, 122 N.E. 1 (1919) (in refusing recovery, carefully mentions that no showing of fraud was made).

22 Huset v. Case Threshing Mach. Co., 120 Fed. 865 (C.A. 8th, 1903). See also Colbert v. Holland Furnace Co., 33 Ill. 78, 164 N.E. 162 (1928); Coughtry v. Globe Woolen Co., 56 N.Y. 124 (1874) (mentioning implied invitation). 
and the ultimate consumer ${ }^{23}$ by spelling out an offer from representations of an intermediate vendor whom they treated as an agent of the manufacturer. Even further removed from the classical rule of nonliability are the food product cases which hold the manufacturer liable on the rationales that: (a) consumers are third party beneficiaries of the implied warranty between the manufacturer and the retailer; ${ }^{24}(\mathrm{~b})$ an implied warranty extends from the manufacturer to the third party even in the absence of contract, i.e., the "warranty runs with the chattel"; ${ }^{25}$ and (c) third parties are assignees of the manufacturer's implied warranty to the retailer..$^{26}$

In view of the extent to which the exceptions to the "general rule" of nonliability have replaced the rule it is difficult to understand why third parties injured by defects in the construction of "realty per se" have not been allowed recovery from builders. ${ }^{27}$ One argument for the denial of recovery is the requirement of inspection. The purchaser of real property, unlike the buyer of chattels, has a duty to inspect the purchased property and thereby assumes the risk of defects. ${ }^{28}$ However, the appraisal of the soundness of the construction of individual components and of the whole dwelling is a unique skill belonging only to the expert in this modern age of building specialization. To say that the purchaser of real property has a duty to inspect is no more than to say that the law will not afford him a remedy if he is injured by a defect, since actually the unaided layman is no more capable of making an adequate inspection of a house than of an automobile. For the prudent purchaser, however, inspection may be no more than a monetary burden since he can hire a contractor or architect to inspect for him, or, in addition, he may secure one of several manuals designed to instruct the layman in the methods and techniques of inspection. This monetary burden is often a real one, however, for V.A. and F.H.A. financing is making possible purchases by persons with only enough capital to cover small down payments on their homes. There is some evidence, as well, that contractors are putting pressure upon such persons not to inspect, and in extreme cases, purchasers are actually being denied the opportunity.$^{29}$ Perhaps the difficulty of

${ }^{23}$ Carlill v. Carbolic Smoke Ball Co., [1893] 1 Q.B. 256; Timberland Lumber Co. v. Climax Mfg. Co., 61 F. 2d (C.A. 3d, 1932).

${ }_{24}$ Madouros v. Kansas City Coca Cola Bottling Co., 230 Mo. App. 275, 90 S.W. 2d 445 (1936). Uniform Commercial Code § 2-318 (1952).

${ }^{25}$ The Requirement of Privity of Parties in Actions for Breach of Warranty in the Sale of Foods, 22 Rocky Mt. L. Rev. 176 (1950).

${ }^{26}$ Escola v. Coca Cola Bottling Co. of Fresno, 24 Cal. 2d 453, 150 P. 2d 436 (1944); and generally, The Requirement of Privity of Parties in Actions for Breach of Warranty in the Sale of Foods, 22 Rocky Mt. L. Rev. 176 (1950).

${ }^{27}$ Ford v. Sturgis, 14 F. 2d 253 (App. D.C., 1926); Schott v. Ingargolia, 180 So. 462 (La. App., 1938).

28 Rest., Torts $\$ 366$ (1934).

292 Hearings before Subcommittee on Housing of the House Committee on Banking and Currency on H. Res. 436, 82d Cong. 2d Sess. (1952). 
inspection has influenced the imposition of liability without regard to the requirement of inspection for injuries from defects in instrumentality like real property, i.e. porch railing, gas heater, and overhead door. ${ }^{30}$ The further argument that "the negligence of the owner in maintaining the defective building, and not that of the builder in constructing it, is the true proximate cause of the third person's injury"31 is necessarily based on this same assumption of a competent inspection.

Another argument for not applying the MacPherson v. Buick exception in cases in which the defect is in realty per se, is that MacPherson 0 . Buick allows suit by a third party against the manufacturer only to eliminate the necessity of suit by the injured party against his vendor and a further suit by the vendor against the manufacturer. Under the reasoning that the injured homeowner has no cause of action against his vendor, ${ }^{32}$ presumably it could be argued that under MacPherson v. Buick he has none against the contractor. This conclusion has been refuted, however, by allowing the injured purchaser of secondhand goods to recover from the manufacturer of the goods, even though there was no cause of action against the vendor. ${ }^{33}$

In support of nonliability, reliance can be placed on a few more or less explicit statements from English cases that the laws of chattels do not apply to realty. ${ }^{34}$ Even if this is the prevailing British rule, ${ }^{35}$ clearly such a distinction is not a hard and fast one in American jurisdictions as demonstrated by the many exceptions, both in real and personal property, from the general rule of nonliability. If in fact American courts rely upon such a distinction, problems of definition and classification arise. One of the more complex classification problems is the determination of when a chattel is sufficiently affixed to real property to lose its identity as a chattel and to become part of the realty. ${ }^{36}$

${ }^{30}$ See authorities cited footnotes 9,10 and 11 supra.

31 Ford v. Sturgis, op. cit. supra note 27, at 254, citing Wharton on Negligence $\$ 439$ (1874).

32 See text at footnote 37 infra.

${ }^{33}$ Beadles v. Servel Inc. \& Union Gas \& Elec. Co., 344 Ill. App. 133, 100 N.E. 2d 405 (1951).

${ }^{34}$ See Bottomly v. Bannister, [1932] 1 K.B. 458; Otto v. Bolton \& Norris, [1936] 2 K.B. 46. For the modern English rule in the chattel field see M'Allister v. Stevenson, [1932] A.C. 562 (snail and bottle case).

${ }^{35}$ The precedents are actually not as strong as indicated in Builder's Liability for Defective Houses, 81 L.J. 290 (1936), for both decisions are also based on other grounds.

${ }^{36}$ It might be urged that when chattels are affixed to real estate they become subject to the Otto v. Bolton \& Norris rule ([1936] 2 K.B.46), and that MacPherson v. Buick is inapplicable. The common law of fixtures knew three principal distinctions in determining whether a "chattel" had become realty. Such items as chairs, being "in their nature" personalty, would retain their personal character despite any contrary agreement of the parties, and the seller's security interest would prevail over that of a bona fide purchaser of the realty. At the opposite extreme were items such as mortar and brick, so inseparable from the realty as not to be removable without a material injury to the freehold. If the item in question were of the second character, the seller's security interest would be lost in a contest with a bona fide purchaser of the realty. The third category consisted of chattels which were not "in their nature" personalty or realty but which could be removed without material injury to the freehold. The 
The persistence of the idea that land is the primary source of wealth and consequently it would be unfair, under a deep pocket theory, to go behind the owner of the land to the contractor-someone who merely erected a structure upon the land-is a possible rationale for not imposing liability upon the builder. There is, however, little or no basis for the presumption that the builder's pocket is not just as deep as that of the manufacturer or of the landowner.

In considering the rights of the injured homeowner who is in a third party relationship to the builder of the completed home, attention must be drawn to the other member of the transaction-the vendor. The prevailing rule allows the vendor to escape liability for injuries from defects existing at the time of the conveyance. ${ }^{37}$ The underlying rationale for this denial of responsibility is found in the technical rules that: (a) there are no implied warranties in the sale of real estate; ${ }^{38}$ (b) express warranties in the contract of sale may be extinguished through merger in the deed; ${ }^{39}$ and (c) the vendee has a duty of inspection and so is presumed to discover all unconcealed defects. ${ }^{40}$

Some inroads into the favored position of the vendor have been made in $\mathrm{New}$

status of these items depended on the intention of the parties at the time the chattel was originally sold. The Uniform Conditional Sales Act preserves the law governing the first two categories, but makes material changes in respect to the third. Section 7 provides that a reservation of the security interest in a chattel which can be removed without material injury to the freehold is void as against a bona fide purchaser of the realty unless the chattel security interest is recorded. But the controversy still rages about the question of what constitutes a "material injury to the freehold." Under the "institutional doctrine," followed in several states, the test is whether the removal of the item would materially affect the use of the premises for the purpose for which they are designed. The physical nature of the item's attachment is held immaterial. A stove, being essential to the use of an apartment, is therefore not removable "without material injury to the freehold." Cf. Smyth Sales Corp. v. Norfork Bldg. and Loan Assn., 116 N.J.L. 293 (1936). A greater number of states have followed the test of physical injury, but the cases are in conflict as to what constitutes a material injury and whether or not a given item is in its "essential nature" personalty. See, e.g., Madfes v. Beverly Development Corp., 251 N.Y. 12 (1929). To introduce such subtleties into the law governing the ability of a real estate owner to recover as against the manufacturer of a furnace which has exploded because of the manufacturer's negligence would be unfortunate. But even assuming a general acceptance of the Otto v. Bolton doctrine, the dissimilarity of exploding furnaces as compared with the question of whether a chattel vendor is to prevail in a contest with a bona fide purchaser of the realty would seem to forestall any argument based upon the law of fixtures. But see Knell v. Morris, 247 P. 2d 352 (Cal., 1952), where precisely this was done. Strangely enough, however, the courts have manifested a willingness to follow the law of fixtures in determining such questions as the applicability of ordinary acceptance rules in cases where houses and necessary utilities have been sold together as a unit. See, e.g., Mead v. Collins Realty Co., 75 A. 2d 705 (Del. Super. Ct., 1950); and Package Mortgage and Optional Future Advances, 65 Harv. L. Rev. 478 (1952).

${ }^{37}$ Stone v. Heyman Bros., 124 Cal. App. 46, 12 P. 2d 126 (1932); Combow v. Kansas City Ground Investment Co., 358 Mo. 934, 218 S.W. 2d 539 (1949); Smith v. Tucker, 151 Tenn. 347, 270 S.W. 66 (1925); Mayer v. Winnipeg Electric Co., [1948] 2 W.W.R. (Manitoba) 869, 4 D.L.R. 301.

384 Williston, Contracts $\$ 926$ (1936). See also the opinion of Atkinson J. in Otto v. Bolton \& Norris, [1936] 2 K.B. 46.

${ }^{39}$ See note 51 infra.

${ }^{40}$ See note 28 supra. 
York. A reasonable time in which to inspect the premises after conveyance is allowed the purchaser where a nuisance exists at the time of conveyance. In addition, the concept of nuisance has been enlarged, under the Multiple Dwelling Law, to include such dangerous conditions as a defective ceiling. ${ }^{41}$ There is also some authority which holds the vendor liable even after the vendee has taken possession where the vendor has failed to disclose or has hidden or concealed some defect in the premises involving an unreasonable risk to persons upon the land. ${ }^{42} \mathrm{~A}$ possible explanation for this authority is that the failure to disclose or the concealing is something like fraud. One might add that it is impossible to discover a concealed defect by inspection.

The doctrine that violation of a statute imposes civil liability for personal injuries which result from such violation is a subject of general discussion in tort law. ${ }^{43}$ The particular application of this doctrine to the injured vendee would be that the vendor is responsible to his vendee for all injuries incurred from conditions which fall below the minimum standards set by building codes. Such liability has been rejected, however. ${ }^{44}$

Perhaps closer analysis of the sales contract for a house not yet built at the time of contracting might provide another method of escaping the general rule that a vendor is not liable for injuries from defects existing at the time of conveyance. This contract can be thought of as two separate contracts-one contract for the purchase of land and another for construction of the house. Under this bifurcation the injured owner might well be able to recover on the construction contract, thus avoiding the difficulties involved in suing the vendor qua vendor.

In seeking recovery, the injured vendee might well consider the slightly more favorable position of the injured lessee. There is substantial similarity between a lessor-lessee and a vendor-vendee relationship, although the two have consistently been distinguished. In Smith $v$. Tucker, ${ }^{45}$ for example, although admitting that a lessee could recover for personal injuries for his landlord's breach of an express promise to repair, the court refused to allow the vendee to recover on a similar promise by the vendor because of "the fundamental difference" in the two relationships. ${ }^{46}$ The "fundamental difference" ordinarily relied upon is the peculiar, quasi-confidential, continuing relation of a landlord to his tenant which gives rise to a measure of control. The landlord retains legal title which

11 Pharm v. Lituchy, 283 N.Y. 130, 27 N.E. 2d 811 (1940).

12 Palmore v. Morris, T. \& Co., 182 Pa. 82, 37 Atl. 995 (1897) (early dicta); accord, Rest., Torts $\$ 353$ (1934).

13 The Restatement of Torts $\$ 286$ (1934) recognizes the possibility of such liability.

4 Stone v. Heyman Bros., 124 Cal. App. 46, 12 P. 2d 126 (1932) (denied liability, though injury was caused by condition of sky light which violated building code).

${ }^{45}$ Smith v. Tucker, 151 Tenn. 347, 270 S.W. 66 (1925).

${ }^{46}$ See ibid., at 69 for the express differences which the court found between the two relationships. 
the tenant is estopped to deny, while the tenant has the right of possession. The landlord maintains a substantial interest in the use of the premises, and in certain instances, may retain express control, such as the right of entry at reasonable times. The landlord so described has a counterpart in the commercial vendor of today who frequently sells his land through the installment land contract. Such a vendor retains legal title until final payment; the vendee, retaining equitable rights and possession, is estopped from denying the vendor's title. Control is frequently retained by covenants to supervise the condition and the use of the property in order to protect the subdivider's interest in his investment. The continuing, quasi-confidential relations between vendor and vendee under the installment land contract seems substantially similar to the lessorlessee relation.

The analogous relation of the vendor and the landlord as regards liability for personal injuries has significance only where there is a promise to correct the defects. ${ }^{47}$ That the landlord should be liable for injuries resulting from the breach of an express promise to repair is a considerable advance from the 19th century rule of caveat emptor. ${ }^{48}$ Even today in the absence of an express promise, the burden of repair is cast upon the tenant, ${ }^{49}$ but there is strong judicial dissent from such a burden.

47 Ibid., and see note 38 supra.

${ }^{48}$ On the subject of development of lessor's duties to lessee see generally, Lessor's Duty to Repair: Tort Liability to Persons Injured on the Premise, 62 Harv. L. Rev. 669 (1949). Although it is exceedingly difficult to talk in terms of minority and majority rules, a clear preponderance of the recent decisions have held that the landlord is liable in tort for the breach of his covenant to repair and that damages are recoverable not only for harm to property but for personal injuries as well. Scholey v. Steele, 59 Cal. App. 2d 402, 138 P. 2d 733 (1943); Asheim v. Fahey, 170 Ore. 330, 133 P. $2 d 246$ (1943). In jurisdictions so holding, no distinction is taken between misfeasance and nonfeasance. Rest., Torts $\$ 357$ (1934). It is also immaterial whether the tenant himself or one who is on the premises with his permission is injured-the landlord is liable in either event. Dean v. Herschowitz, 119 Conn. 398, 177 Atl. 262 (1935). Under the traditional view the landlord is liable in tort only if he undertakes to repair, and then repairs negligently. If he fails to do anything, the tenant's measure of recovery is the difference between the rental value of the premises in a repaired and in an unrepaired state. Williams v. Fenster, 103 N.J.L. 566, 137 Atl. 406 (1927). The cases are collected in 163 A.I.R. 300 et seq. (1946). It is quite generally held that damages for personal injuries cannot be recovered in an action on the contract to make repairs. For a list of cases in thirteen states, see 163 A.L.R. 329-30 (1946). Rest., Torts $§ 357$, Comment a (1934), states that the lessor's duty is not contractual but is a tort duty. It was said in the Williams case, supra, that the measure of damages for a breach of an agreement to repair is the difference between the rental value in a repaired and in an unrepaired state.

${ }^{49}$ There are some exceptions to this rule however: (1) statutes, which require the landlord to put and keep certain types of premises, such as tenement houses, in repair have been held to impose liability in tort upon him for failure to do so, cases cited in Prosser, Torts, $650 \mathrm{n} .30$ (1941); (2) where land is leased for a purpose which involves the admission of the public, the lessor is under an affirmative duty to exercise reasonable care to inspect and repair the premises before possession is transferred. Prosser, Torts 653 (1941); (3) on the letting of the completely furnished house for immediate occupancy, an implied agreement arises that the house and appointments are fit for use, Hacker v. Nitschke, 310 Mass. 754, 39 N.E. 2d 644 (1942). Agreement which arises may extend only to furniture, Fisher v. Pennington, $116 \mathrm{Cal}$. App. 248, 2 P. 2d 518 (1931). 
I think that rule [putting the burden of repair on the tenant] is an anachronism which has lived on through stare decisis alone rather than through pragmatic adjustment to "the felt necessities of [our] time." I would therefore discard it and cast the presumptive burden of liability upon the landlord. This, I think, is the command of the realities and mores of our day. ${ }^{50}$

Even after the successful demonstration of the landlord-tenant analogy, the vendee meets a further difficulty in seeking compensation for personal injuries from breach of an express promise. This difficulty is in the doctrine that the "acceptance of a deed of conveyance ... discharges the contractual duties of the seller to the parties so accepting." the condition of the premises contained in the deed. ${ }^{52}$ Agreements "collateral" to the main purpose of the sales contract, however, are an exception to the merger rule and consequently are not extinguished by deed..$^{53}$ The vendee must, then, prove that the promises on which he relies fall within this exception. The authority on which the proving of the collateral nature of promises to repair and correct defects must rely is found almost exclusively in contract actions. ${ }^{54}$ In these cases, however, agreements to repair a dam, ${ }^{55}$ to make improvements, ${ }^{56}$ and to remedy deficiencies in construction of a house,${ }^{57}$ similar to agreements to repair and correct defects, have been held to be collateral, and thus excluded from the operation of the merger doctrine. This relaxation of the merger doctrine, allowing the vendee to recover on such express agreements, may provide a major inroad into the rule of caveat emptor in sales of land. ${ }^{58}$ This is of key significance in view of the fact that there are no implied warranties in such sales.

Although there usually is considered to be an implied warranty of fitness or merchantability in the sale of goods, ${ }^{59}$ it is generally acknowledged that the

${ }^{80}$ Bazelon, J. dissenting in Bowles v. Mahoney, App. D.C., No. 109347 (July 10, 1952), a case which placed the burden of making repairs upon the tenant.

s1 Rest., Contracts $\S 413$ (1932); Asbury v. Cochran, 243 Ala. 281, 9 So. $2 d 887$ (1942); Wing v. Forest Lawn Cemetery Ass'n, 15 Cal. 2d 472, 101 P. 2d 1099 (1940).

${ }^{52}$ There appears little reason why the purchaser by installment and contract should be confronted with the merger doctrine, since conveyance by deed occurs only after full purchase payment has been made.

${ }^{53}$ Rest., Contracts $\$ 413$ (1932).

54 But see Smith v. Tucker, 151 Tenn. 347, 270 S.W. 66 (1925).

${ }^{65}$ Shelby v. Chicago \& E. I. R. Co., 143 Ill. 385 (1892).

${ }^{68}$ Saville v. Chalmers, 76 Ia. 325, 41 N.W. 30 (1888).

b7 Haynes v. Morton, 32 Tenn. App. 251, 222 S.W. 2d 389 (1949).

${ }^{68}$ For the point that builders are voluntarily making good on express promises, see Levitt's Progress, 46 Fortune, No. 4, at 154, 158 (October, 1952): "They make it a prectice to give a one-year warranty-unwritten, to be sure-on every house. The practice cost them $\$ 250,000$ a year on Long Island."

62 Uniform Sales Act, 1 U.L.A. $\$ 15$ (1950). 
purchaser of real estate is not protected by such an implied warranty.$^{60}$ It has been suggested that the purpose of implied warranties in the sale of chattels is to shift the immediate incidence of the hazard of life in an industrial society away from the individual over to a group which can distribute the loss; and ... to keep down future losses. . . . The customer, barring his own fault in use, should have no negligence to prove.61

In view of the fact that many vendors of new housing are large commercial developers in the business of selling houses as other merchandisers are in the business of selling chattels, similar objectives for governing the allocation of hazard in the sale of real property seem appropriate. It would therefore seem proper to provide purchasers of real estate with the same legal remedies against their vendors as buyers of merchandise now enjoy against their sellers. ${ }^{62}$

Since a considerable number of vendees purchase their homes, not from large commercial developers, but from individual homeowners who cannot spread the monetary cost of damages, it might be contended that the introduction of implied warranties into such transactions would be inconsistent with their loss spreading objectives. But it must be recognized in the instance of the sale by the individual of his own home that the home is secondhand. Normally, there are no implied warranties in the sale of secondhand articles, ${ }^{63}$ the duty of the seller being only to inform the buyer of any known defects. ${ }^{64}$ Ordinarily, then, liability would only be shifted to the large, commercial vendor of new homes. ${ }^{65}$ The large, commercial vendor of reconditioned, secondhand homes, however, would be able to spread the costs of damages. The imposition of liability on such

${ }^{60}$ Hart v. Windsor, 12 M. \& W. 68 (1843), is the leading case rejecting such warranties in the sale of housing. But there are other implied warranties in sales of chattels, i.e., "Where there is a contract to sell or a sale of goods by description, there is an implied warranty that the goods shall correspond with the description." Uniform Sales Act, 1 U.L.A. \$ 14 (1950). It has been suggested that this rule applies in sales of land at least where the description is a statement of the quantity of land to be sold. 2 Warvelle, Vendor and Purchaser 839 (1890). It also appears to be a law of real property that if there is a contract to sell a house to be built in the future entered into on the basis of a description in the sense of the vendor showing the purchaser the plans of the house, an implied warranty arises that the house will be like the plans, and this warranty does not merge in the deed. Stevens v. Milestone, $190 \mathrm{Md}$. $61,57 \mathrm{~A}$. 2d 292 (1948); Laurel Realty Co. v. Himelfarb, 191 Md. 462, 62 A. 2d 263 (1948).

01 Llewellyn, Cases and Material on the Law of Sales 341 (1930).

22 For a suggestion that there are exceptions to the prevailing view that in land transactions there is no implied warranty of fitness or merchantability "capable of destroying the rigorousness of the rule," see Dunham, Modern Real Estate Transactions, Cases and Materials 481 (1952).

${ }^{83}$ Bayer v. Winton Motor Car Co., 194 Mich. 222, 160 N.W. 642 (1916); Hysko v. Morawski, 230 Mich. 221, 202 N.W. 923 (1925).

e4 Bergstre.ser v. Van Hoy, 142 Kan. 88, 45 P. 2d 855 (1935); Rest., Torts § 388 (1934).

${ }^{65}$ Such liability may be useful as a deterrent for the reason that many housing developers move frequently from one community to another and consequently may not be as affected as others by the ordinary extra-legal, public relations sanctions. 
vendors could be based on the law in the chattel field that a rebuilder or reconditioner of goods has substantially the same duty as a manufacturer. ${ }^{66}$

At first glance, the imposition of Section 15 of the Uniform Sales Act to real estate transactions would appear to present a dilemma to the prospective home buyer, confronting him with the alternatives of purchasing a house with which he is not familiar or assuming the risks of defects. Upon further analysis, however, it becomes clear that section 15(3) negates implied warranties only "as regards defects which such examination ought to have revealed." Since the average purchaser has little technical knowledge of houses, it cannot be presumed that his superficial inspection "ought" to reveal any but the most patent defects. However, because the layman presumably realizes the limitation of his knowledge, inspection does not preclude his reliance upon the "skill or judgment" of the vendor. ${ }^{67}$

Even under a liberal application of implied warranties to real property, the purchaser of a secondhand house from an individual vendor has only a limited possibility of recovery from his vendor. If the injuries resulted, however, from defects existing before the purchase by this individual vendor from a largescale, commercial developer, the injured homeowner may be able to recover from the developer. Recovery would be grounded on an analogy to the principle found in the law of chattels that when a seller holds himself out to the public as the producer of the article he sells, he is liable as if he were the producer. ${ }^{68}$ It is arguable that the large-scale developer places himself in the position of the builder, for he seeks public faith in his name and in his competence.

The above discussion has indicated several lines of argument that the courts could utilize to extend greater protection to purchasers of real estate. With the growth and commercialization of building construction, it is possible that such arguments will be used to allocate more equitably the burden of injuries from defective housing.

\section{FORESEEABIITY OF THIRD-PARTY ECONOMIC INJURIES-A PROBLEM IN ANATYSIS}

The problem of analysis presented by two independent streams of legal doctrine converging to form the basis for a possible new tort has occasioned much judicial confusion. Protection of plaintiff's economic interest incidentally damaged as a result of a negligent tort either to himself or to his individual property has traditionally been afforded by general tort law. But where the defendant

๓ Flies v. Fox Brothers Buick Co., 196 Wis. 196, 218 N.W. 855 (1928) (allowed recovery on a MacPherson v. Buick rationale).

${ }^{67}$ For the necessity of such reliance, see Uniform Sales Act, 1 U.L.A. $\$ 15(1)$ (1950).

${ }^{88}$ Slavin v. Legget \& Co., 114 N.J.L. 421, 177 Atl. 120 (1935) (holding vendor liable who put label on can of peas canned by someone else). See Schechter, The Rational Basis of Trademark Protection, 40 Harv. L. Rev. 813 (1927). 